\title{
Taxonomy of Traditional and Modern Architectural Styles of Heritage Shophouse Facade at Ipoh, Perak, Malaysia
}

\author{
Wan Nordiana Wan Ali, A. Ghafar Ahmad
}

To Link this Article: http://dx.doi.org/10.6007/IJARBSS/v10-i11/8366

DOI:10.6007/IJARBSS/v10-i11/8366

Received: 20 September 2020, Revised: 22 October 2020, Accepted: 14 November 2020

Published Online: 28 November 2020

In-Text Citation: (Ali \& Ahmad, 2020)

To Cite this Article: Ali, W. N. W., \& Ahmad, A. G. (2020). Taxonomy of Traditional and Modern Architectural Styles of Heritage Shophouse Facade at Ipoh, Perak, Malaysia. International Journal of Academic Research in Business and Social Sciences, 10(11), 1426-1437.

\section{Copyright: (c) 2020 The Author(s)}

Published by Human Resource Management Academic Research Society (www.hrmars.com)

This article is published under the Creative Commons Attribution (CC BY 4.0) license. Anyone may reproduce, distribute, translate and create derivative works of this article (for both commercial and non-commercial purposes), subject to full attribution to the original publication and authors. The full terms of this license may be seen at: http://creativecommons.org/licences/by/4.0/legalcode

Vol. 10, No. 11, 2020, Pg. 1426 - 1437

Full Terms \& Conditions of access and use can be found at http://hrmars.com/index.php/pages/detail/publication-ethics 


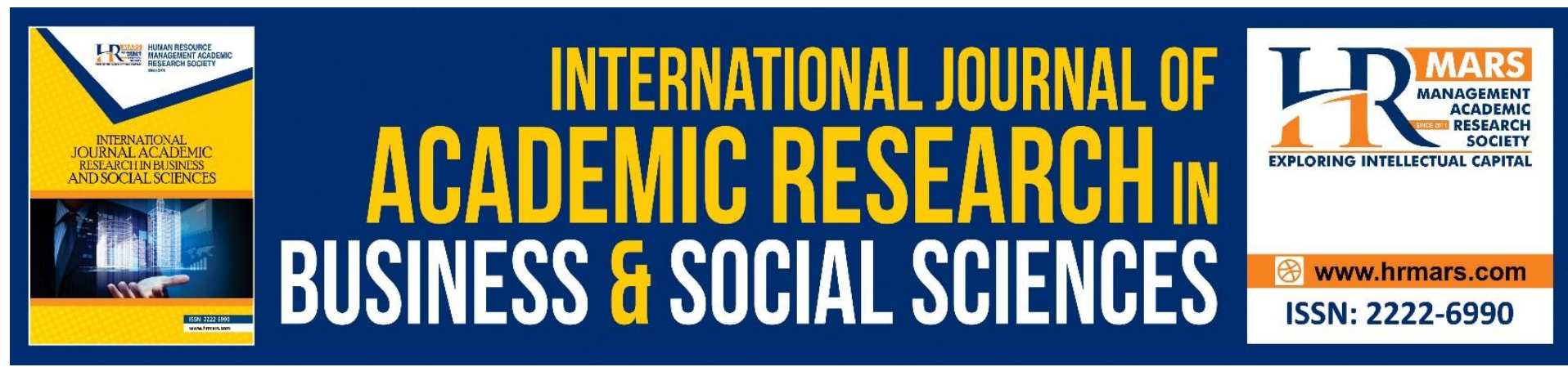

\title{
Taxonomy of Traditional and Modern Architectural Styles of Heritage Shophouse Facade at Ipoh, Perak, Malaysia
}

\author{
Wan Nordiana Wan Ali ${ }^{1,2}$, A. Ghafar Ahmad ${ }^{1}$ \\ ${ }^{1}$ School of Housing, Building and Planning, Universiti Sains Malaysia, ${ }^{2}$ Department of \\ Building, Faculty of Architecture, Planning and Surveying, Universiti Teknologi MARA Perak \\ Malaysia
}

\begin{abstract}
Ipoh, once was the most productive tin ore field in Malaysia, has faced development growth that caused an immense number of dwellings called the shophouse that was built along the street since the colonial era. Many of them are still survive until today and become the cultural heritage property. The unique feature of the shophouse is the various architectural styles of the façade due to the revolution of the architectural design movement. Among these styles, the significantly different shape is traditional and modern. This paper discusses on a research that aims to establish a taxonomy to classify the characters that distinguish the traditional and modern styles of heritage shophouse façade in Ipoh, Malaysia. The results were obtained through a literature review and data analysis from the fieldwork. It shows that several characters portray the identity of traditional and modern styles that can be seen on the structure, building enclosure, opening, fenestration, and ornamentation. The findings may add knowledge in the process of classifying architectural styles of the heritage shophouse facade in Ipoh for the purpose of documentation, conservation, or restoration of the original design of the building facade.
\end{abstract}

Keywords: Taxonomy, Architectural Styles, Heritage Shophouse, Facade.

\section{Introduction}

Malaysia has many fascinating places, and that includes major towns with a lot of heritage buildings, mainly urban dwelling known as shophouse. One of the most attractive towns is Ipoh, Perak, which is located at the northern peninsular of Malaysia. Ipoh has 1,022 units of heritage shophouses as stated in Special Area Plan of Ipoh 2020 (2014). However, according to Nik and Mohd (2017), this architectural asset has been affected as a result of the surrounding development and building occupancy that have gone through phases of changes, modifications, and additions to meet the needs of living. This situation currently happens to the heritage shophouses in Ipoh. The inappropriate changes on the tangible elements of the building façades have caused difficulty in documenting and inventory purposes to determine the originality and classification of the architectural styles. Hence, there is an essential need to preserve and protect the integrity form of the building facade from being altered or destroyed, which requires determination and commitment from the owners, local authorities 
and the public. Other than documentation movement, intervention also should be taken to prevent decay and manage change dynamically as long as adhere to the conservation principal (Ghafar, 2010). Fielden (2003) described conservation as approaches that prolong the life of cultural and natural heritage that include; preservation, prevention, consolidation, restoration, rehabilitation, reproduction, reconstruction, adaptive reuse, maintenance, reconstitution, and replica.

Table 1. Examples of current condition of heritage shophouse facades in Ipoh.

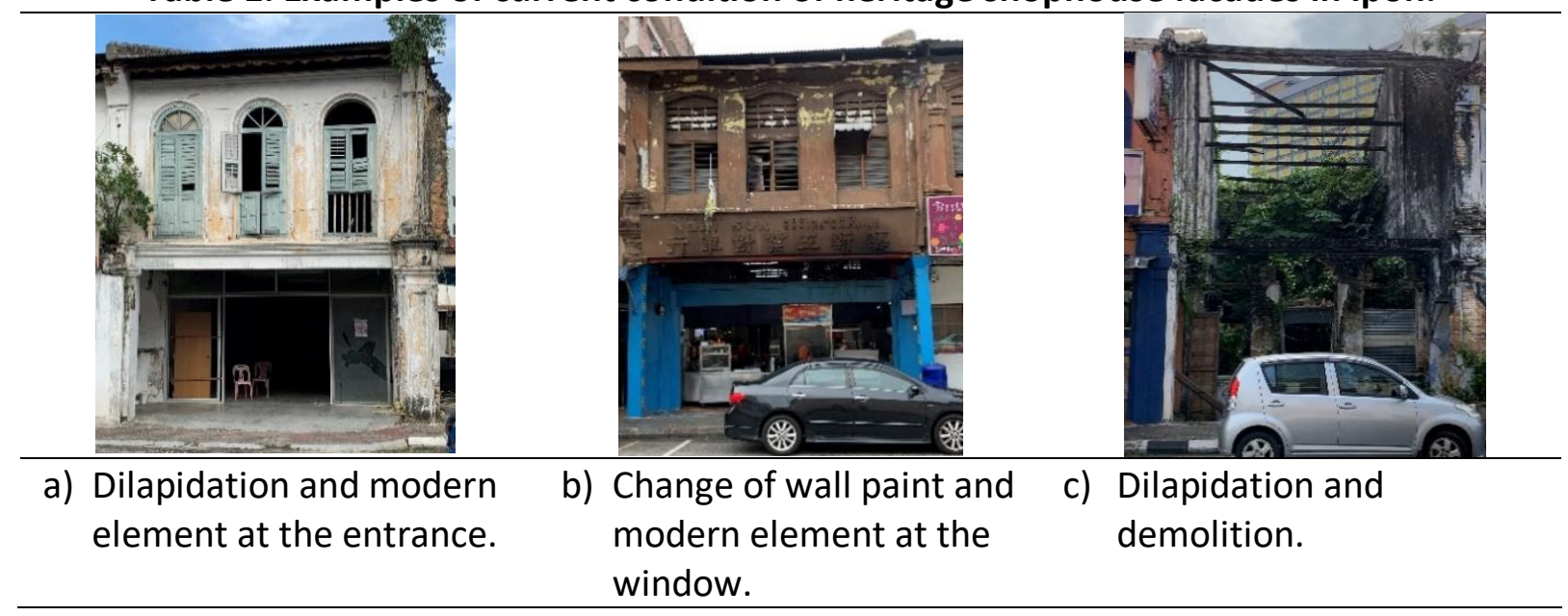

The focal part of the shophouses that should be prioritised is the building's front façade. It is a significant component as the medium in conveying the image and identity of the architectural structure (Vozniak \& Butyrin, 2019). Besides, it also relates to memory, values, and sense of a place for the next generations (Dogan, 2019). According to Shalunts et al. (2011), there is no automatic system for the classification of building facade images by architectural styles. If an observer does not have the knowledge in classifying the architectural styles, it is difficult for the observer to find out which architectural style of the building it belongs to. Shalunts et al. (2011) added that the architectural style classification of the facade is viewed as a voting mechanism of separate architectural elements. Therefore, for this research, a taxonomy for the classification of characteristics for two major categories of architectural styles, traditional and modern, may reduce the ambiguity in distinguishing the styles specifically for the heritage area of Ipoh. Taxonomy is defined as (Hornby, 2008):

The scientific process, technique or particular system of classifying things such as arranging them into groups to create a systematic order.

From the definition, this approach seems appropriate for the shophouse facades with a mix of different architectural styles, even in the same building block. The various design of the heritage building facade is due to the construction period, regions of construction, owner wealth status, and construction team.

\section{Research Background}

The Kinta Valley in Perak had seen small-scale Malay mining in about 1880 before the influx of Chinese immigrants that transformed the industry. Architecturally, the city centre is characterised by a colonial-era Chinese shophouse and several impressive historical buildings from the British Colonial era. Many heritage shophouses had gone into a series of evolution 
on their building façade since the 1880s till the 1970s. It begins with the Neo-Classical and Transitional architectural styles that were introduced as early as the 1880 s, followed by Eclectic in the 1890s. Between the period of the 1925s until the 1950s, Art Deco was introduced, followed by Early Modern and Modern design from 1940s to 1970s. Table 2 shows the numbers of shophouse in Ipoh with different styles of façade.

Table 2. Numbers of heritage shophouse in Ipoh.

\begin{tabular}{|c|c|c|c|c|}
\hline No. & Styles & Year & Unit & $\%$ \\
\hline 1 & Transitional & 1880-1900s & 280 & 27.4 \\
\hline 2 & Eclectic & 1890-1930s & 365 & 35.7 \\
\hline 3 & Neo-Classical & 1880-1920s & 45 & 4.4 \\
\hline 4 & Art Deco & 1925-1950s & 44 & 4.3 \\
\hline 5 & Early Modern & 1940-1970s & 220 & 21.5 \\
\hline \multirow[t]{2}{*}{6} & Modern & 1970s & 68 & 6.7 \\
\hline & & Total & 1,022 & 100 \\
\hline
\end{tabular}

(Majlis Bandaraya Ipoh, 2014).

The local authority had taken an initiative to zone the Heritage Area as stated in Special Area Plan of Ipoh 2020 (2014) and had been gazetted on 18 ${ }^{\text {th }}$ of December 2014 due to the provision of Town and Country Planning Act (Act 172) as to ensure these architectural assets are well preserved. The heritage area of Ipoh consists of the Old Town and New Town, as shown in Figure 1.

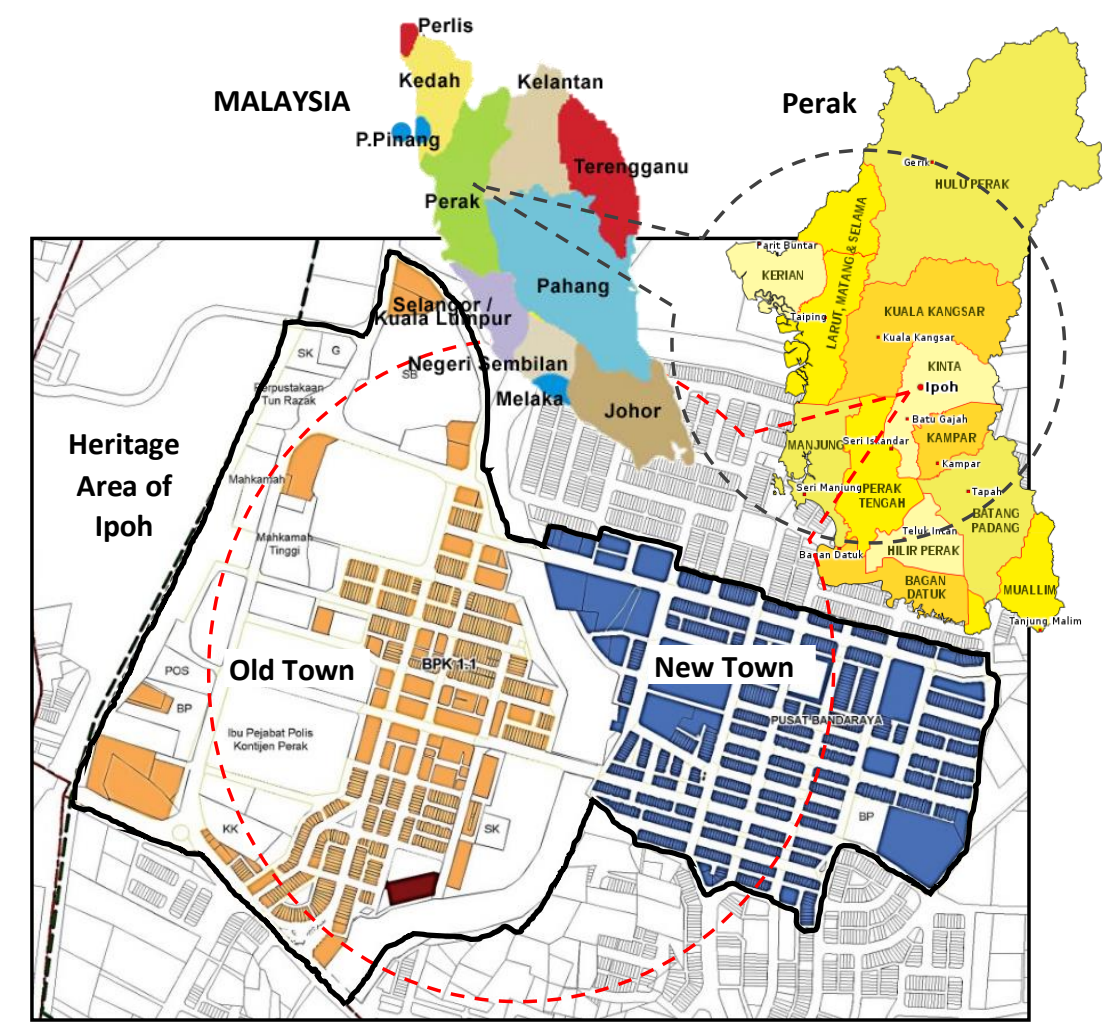

Figure 1. Location of Heritage Area of Ipoh in Perak, Malaysia.

(Majlis Bandaraya Ipoh, 2012; Frontdesk, n.d.; Wikimedia Commons, n.d.). 


\section{Literature Review}

According to Gurstein (1990), Malaysian architecture has distinct characteristics which vary according to several criteria as shown on Table 3:

Table 3. Characteristics of Malaysian architecture criteria.

\begin{tabular}{|c|c|}
\hline Criteria & Characteristics \\
\hline $\begin{array}{l}\text { Rural/urban } \\
\text { differences }\end{array}$ & $\begin{array}{l}\text { Buildings are usually free-standing, made of timber and raised off the } \\
\text { ground on piers in rural areas. Whereby in urban areas, they are } \\
\text { attached buildings of brick and concrete construction with foundations } \\
\text { firmly on the ground. }\end{array}$ \\
\hline $\begin{array}{l}\text { Cultural } \\
\text { differences }\end{array}$ & $\begin{array}{l}\text { The Chinese in the urban streets have interior courtyards that afford } \\
\text { family privacy differs from the Malay in the rural settlement with a } \\
\text { conception of scattered development with no clear boundaries between } \\
\text { houses. }\end{array}$ \\
\hline $\begin{array}{l}\text { Geographical } \\
\text { differences }\end{array}$ & $\begin{array}{l}\text { The traditional Malay house type varies according to the region as the } \\
\text { house is attributable to the proximity to other cultures such as the Thais } \\
\text { in northern Malaysia and the Minangkabaus of Sumatra in Western } \\
\text { Malaysia. }\end{array}$ \\
\hline $\begin{array}{l}\text { Political } \\
\text { differences }\end{array}$ & $\begin{array}{l}\text { States under less foreign control retained more of their traditional Malay } \\
\text { vernacular than those with considerable exposure to external elements. }\end{array}$ \\
\hline $\begin{array}{l}\text { Historical } \\
\text { period }\end{array}$ & $\begin{array}{l}\text { The period of time when a building was constructed give influences to } \\
\text { the styles of the building and façade treatment that varies according to } \\
\text { the typical styles at that time. }\end{array}$ \\
\hline
\end{tabular}

(Gurstein, 1990).

The adaptation of characteristics of Malaysian architecture described in Table 2, can be found in the design of the heritage buildings in Malaysia. The shophouse for instead, was made of brick or concrete and constructed directly on the ground, have interior courtyards, and various architectural styles of the facade got influenced by the local and foreign architecture. All the criteria are combined to form a unique architectural design and series of evolution that reflects the diversity of cultural influences and society in Malaysia. The evolution or transitional changes of design are part of the process of adaptation of climates, local cultural, economic demands, fashion influence and introduction of new technologies (Wooi, 2015).

The shophouse is a hybrid building form with a dwelling above and a ground floor shop facing the road. The building built as part of a one to three storeys height terrace, with their upper floor overhanging the ground floor to form a pedestrian covered walkway (Fee, 2007). The component of the shophouse is façade, commercial area, air well, dining, kitchen, and bedrooms. From architectural perspective, façade is vital as it is capable of communicating the function and significance of a building. In addition, it defines an interior space which it shelters (Comerma, 2008). According to Burden (1996), the word 'façade' comes from the Latin facies, face, and has come to mean the principal front (Curl, 2006; Hornby, 2008) of exterior elevation or face of a building (Tyler, 2000) as seen from the street or other public place (Comerma, 2008). It is also always containing an entrance and characterised by an elaboration of stylistics details (Burden, 2003) and distinguished by its architectural treatment (Ching, 2012). The stylistic of heritage shophouse incorporating architectural vocabulary of four main cultural, which include Malay, Southern Chinese, Sino-European, and Anglo-Indian (Gurstein, 1990). Later, mass-developed shophouse after the 1960s is perceived as non- 
cultural importance and categorised as contemporary shophouse with the advent of International Modernism and the move away from excessive ornamentation (Elnokaly, 2014).

Table 4 shows the elements of the shophouse façade that consists of enclosure, structure, fenestration, ornamentation and openings (Burden, 1996 \& 2003; Wooi, 2015; Hopkins, 2013; Ching, 2012; Fee, 1998; Curl, 2006; Patwell et al., 2000; Gurstein; 1996; Harris, 1983; Ahmad \& Shaiful, 2012).

Table 4. Elements of typical heritage shophouse façades.

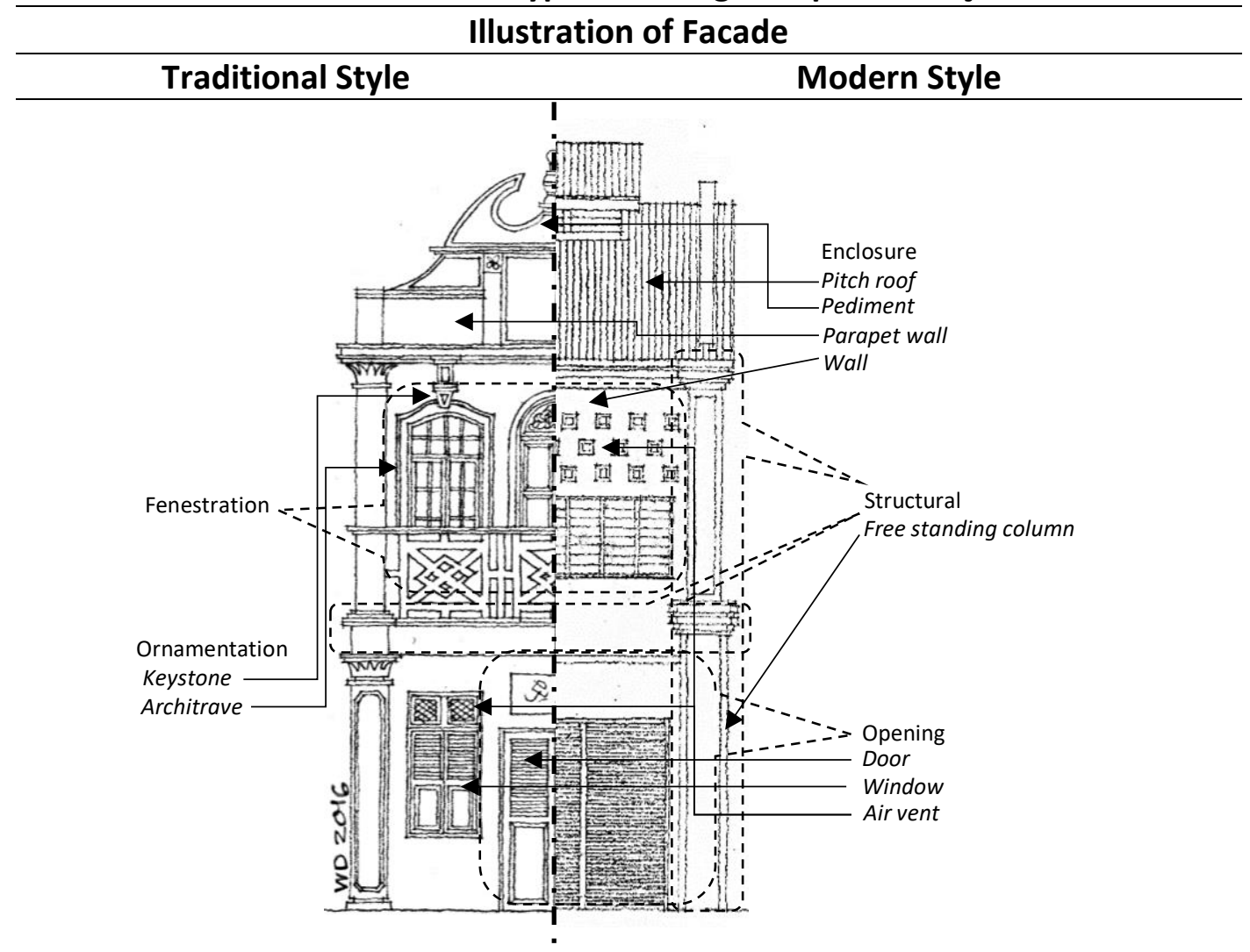


(Wan et al., 2016).

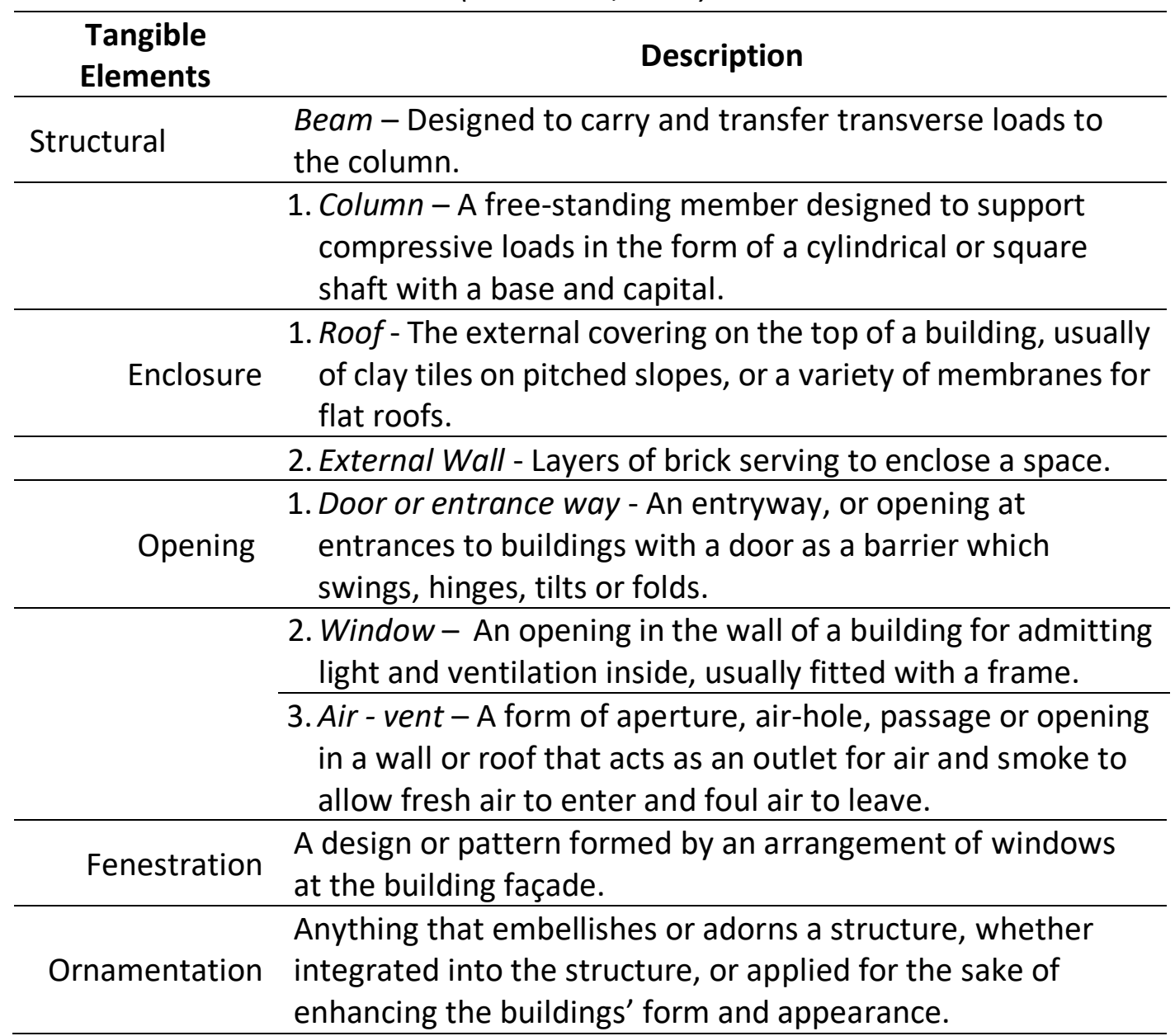

(Burden, 1996 \& 2003; Wooi, 2015; Hopkins, 2013; Ching, 2012; Fee, 1998; Curl, 2006;

Patwell et al., 2000; Gurstein; 1996; Harris, 1983; Ahmad \& Shaiful, 2012).

According to Vozniak and Butyrin (2019); Mughal (2019), the diversity of facade decorative elements, which is categorised as ornamentation, is hard to study. These features also provide sensible qualities that depend on shape, color, texture, and pattern (Ching, 2008 \& Elnokaly, 2014). The aesthetic quality of such a heritage shophouse is the desired relationship of building to its original position, adjacent properties, and the neighborhood. Figure 2 illustrates the evolution typology of heritage shophouse façades at Ipoh from traditional to the modern era.

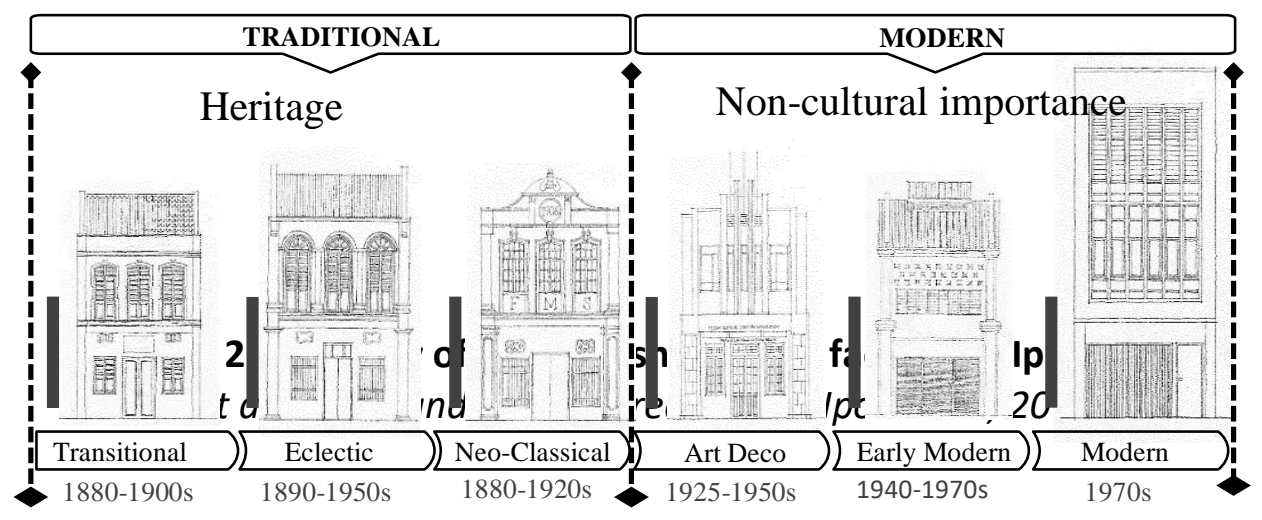




\section{Research Methodology}

This research began with a preliminary interview with an officer of Ipoh City Council (Majlis Bandaraya Ipoh) to identify the relevant issues regarding the heritage shophouse. Once the problems are identified, a literature review starts with the collection of research papers, relevant documents, government reports, reference books, and others to extract the essential data. The information relating to the architectural style of heritage shophouse is collected and analysed. A framework of main tangible elements and sub-elements for heritage shophouse façade is established which includes; structural - beam and column; building enclosure - roof and external wall; Opening - door, window, and air vents, fenestration, and ornamentation.

A checklist was developed to be used in the fieldwork. Thirty units of heritage shophouse facades in Ipoh were selected and reviewed through purposive sampling. The survey was carried out around the Heritage Area of Ipoh by conducting observation and snap photos. The selection criteria of the facade are; visually, it is still in good condition without major intervention or modification and displays its original characteristics of which is presented. Five samples of each architectural style of the shophouse façade were selected, and they are; Transitional, Eclectic, Neo-Classic, Art Deco, Early Modern and Modern. The style of the facade is identified by referring to the basic characters that represent the styles by referring to the information obtained from the literature review. The assessment of each façade is using the checklist. The reason of the fieldwork is to get the primary data of the physical look and condition of the shophouses at Ipoh. All the data is gathered according to its category; traditional and modern styles. The similarities patterns, the differences, and special features of the characters are recorded as primary data of the research. The result of the analysis is used to establish the taxonomy of traditional and modern styles of facade. Lastly, the report of the research is prepared. Figure 3 illustrates how research is conducted.

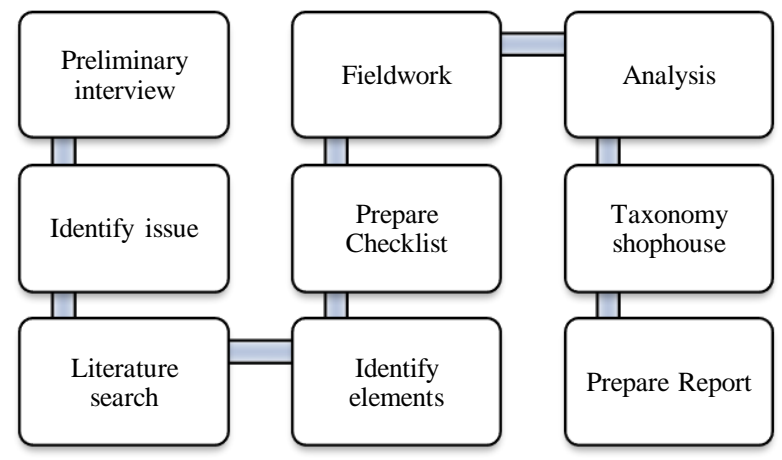

Figure 3. The research process.

\section{Findings and Discussion}

From the literature review, a number of architectural characters forming the heritage shophouse façades according to the styles had been identified and listed in Table 5. 
Table 5. Characters comparison of traditional and modern façade.

\begin{tabular}{|c|c|c|c|c|c|c|c|c|c|}
\hline \multirow{2}{*}{\multicolumn{2}{|c|}{$\begin{array}{c}\text { Tangible } \\
\text { Elements }\end{array}$}} & \multirow[b]{3}{*}{ Characters } & \multicolumn{3}{|c|}{ Traditional } & \multicolumn{3}{|c|}{ Modern } & \multirow{3}{*}{ 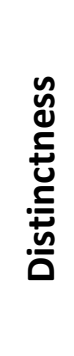 } \\
\hline & & & & & & & & & \\
\hline 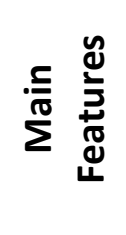 & $\begin{array}{c}\text { Sub- } \\
\text { features }\end{array}$ & & 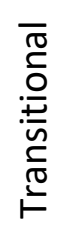 & $\frac{\stackrel{U}{U}}{\frac{U}{U}}$ & 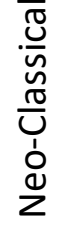 & 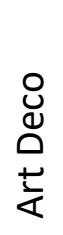 & $\begin{array}{l}\frac{5}{0} \\
\frac{1}{0} \\
\frac{0}{2} \\
\frac{2}{2} \\
\frac{1}{0} \\
\amalg\end{array}$ & $\begin{array}{l}\frac{5}{0} \\
\frac{1}{0} \\
\frac{0}{2}\end{array}$ & \\
\hline \multirow{7}{*}{ 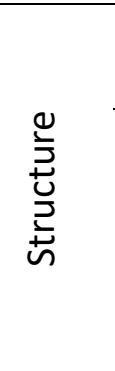 } & \multirow[t]{2}{*}{ Beam } & a. Clay Brick & $\bullet$ & $\bullet$ & $\bullet$ & & & & $\mathrm{V}$ \\
\hline & & b. Reinforce concrete & & & & $\bullet$ & $\bullet$ & $\bullet$ & $\sqrt{ }$ \\
\hline & \multirow[t]{5}{*}{ Column } & c. Clay Brick & $\bullet$ & $\bullet$ & $\bullet$ & & & & $\mathrm{V}$ \\
\hline & & d. Reinforce concrete & & & & $\bullet$ & $\bullet$ & $\bullet$ & $\mathrm{V}$ \\
\hline & & e. Free Standing column & $\bullet$ & $\bullet$ & $\bullet$ & $\bullet$ & $\bullet$ & & \\
\hline & & f. Five-foot walkway without column & & & & & & $\bullet$ & $\mathrm{V}$ \\
\hline & & g. Engage column at the upper level & $\bullet$ & $\bullet$ & $\bullet$ & $\bullet$ & $\bullet$ & $\bullet$ & \\
\hline \multirow{10}{*}{ 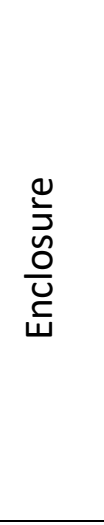 } & \multirow[t]{5}{*}{ Roof } & h. Pitch roof & $\bullet$ & $\bullet$ & $\bullet$ & $\bullet$ & $\bullet$ & & \\
\hline & & i. Flat roof & & & & & $\bullet$ & $\bullet$ & $\mathrm{V}$ \\
\hline & & j. Greek style pediment & & & $\bullet$ & & & & $\mathrm{V}$ \\
\hline & & k. High pediment & & & & $\bullet$ & & & $\mathrm{V}$ \\
\hline & & I. Parapet wall & & & & & $\bullet$ & $\bullet$ & $\mathrm{V}$ \\
\hline & \multirow{5}{*}{$\begin{array}{l}\text { External } \\
\text { wall }\end{array}$} & m. Paint in pastel colour & $\bullet$ & & $\bullet$ & & & & $\mathrm{V}$ \\
\hline & & n. Paint in bright colour & & $\bullet$ & & & & & $\mathrm{V}$ \\
\hline & & o. Paint in shade colour & & & & & $\bullet$ & $\bullet$ & $\mathrm{V}$ \\
\hline & & p. Shanghai plaster & & & & $\bullet$ & & & $\sqrt{ }$ \\
\hline & & q. Wall tiles & & $\bullet$ & & & & $\bullet$ & \\
\hline \multirow{15}{*}{ 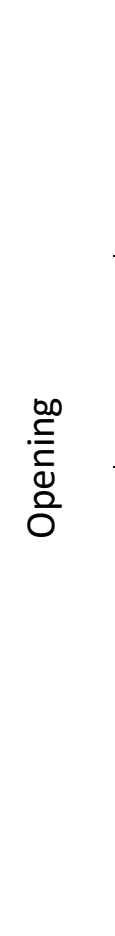 } & \multirow[t]{3}{*}{ Door } & r. Timber door & $\bullet$ & $\bullet$ & $\bullet$ & & & & $\sqrt{ }$ \\
\hline & & $\begin{array}{l}\text { s. Removable or folding timber } \\
\text { panelling }\end{array}$ & & $\bullet$ & $\bullet$ & & & & $\sqrt{ }$ \\
\hline & & $\begin{array}{l}\text { t. Removable or folding metal } \\
\text { panelling }\end{array}$ & & & & & $\bullet$ & & $\mathrm{V}$ \\
\hline & \multirow[t]{4}{*}{ Window } & u. Timber shutter & $\bullet$ & $\bullet$ & $\bullet$ & & & & $\mathrm{V}$ \\
\hline & & v. Casement shutter & & & & $\bullet$ & $\bullet$ & $\bullet$ & $\sqrt{ }$ \\
\hline & & w. Glass louvres & & & & $\bullet$ & $\bullet$ & & $\mathrm{V}$ \\
\hline & & $x$. Concrete shading fin & & & & & $\bullet$ & & $\sqrt{ }$ \\
\hline & \multirow[t]{8}{*}{ Air vents } & y. Timber carved / ceramic slot & $\bullet$ & $\bullet$ & $\bullet$ & $\bullet$ & & & \\
\hline & & z. Concrete slot & & & & & $\bullet$ & & $\mathrm{V}$ \\
\hline & & $\begin{array}{l}\text { aa. Timber or metal lattice at the } \\
\text { ground level }\end{array}$ & & $\bullet$ & $\bullet$ & & $\bullet$ & $\bullet$ & \\
\hline & & bb. Timber carved transomlight & $\bullet$ & $\bullet$ & $\bullet$ & & & & $\mathrm{V}$ \\
\hline & & cc. Timber carved fanlight & $\bullet$ & $\bullet$ & $\bullet$ & & & & $\mathrm{V}$ \\
\hline & & dd. Radiating bars fanlight & $\bullet$ & $\bullet$ & $\bullet$ & & & & $\mathrm{V}$ \\
\hline & & ee. Louvres above window & & & & & $\bullet$ & & $\sqrt{ }$ \\
\hline & & ff. Casement above window & & & & $\bullet$ & $\bullet$ & $\bullet$ & $\mathrm{V}$ \\
\hline \multirow{2}{*}{\multicolumn{2}{|c|}{ Fenestration }} & gg. 2-3 bay full length shutters & $\bullet$ & $\bullet$ & $\bullet$ & $\bullet$ & & & \\
\hline & & hh. Large size & & & & & $\bullet$ & $\bullet$ & $\sqrt{ }$ \\
\hline
\end{tabular}




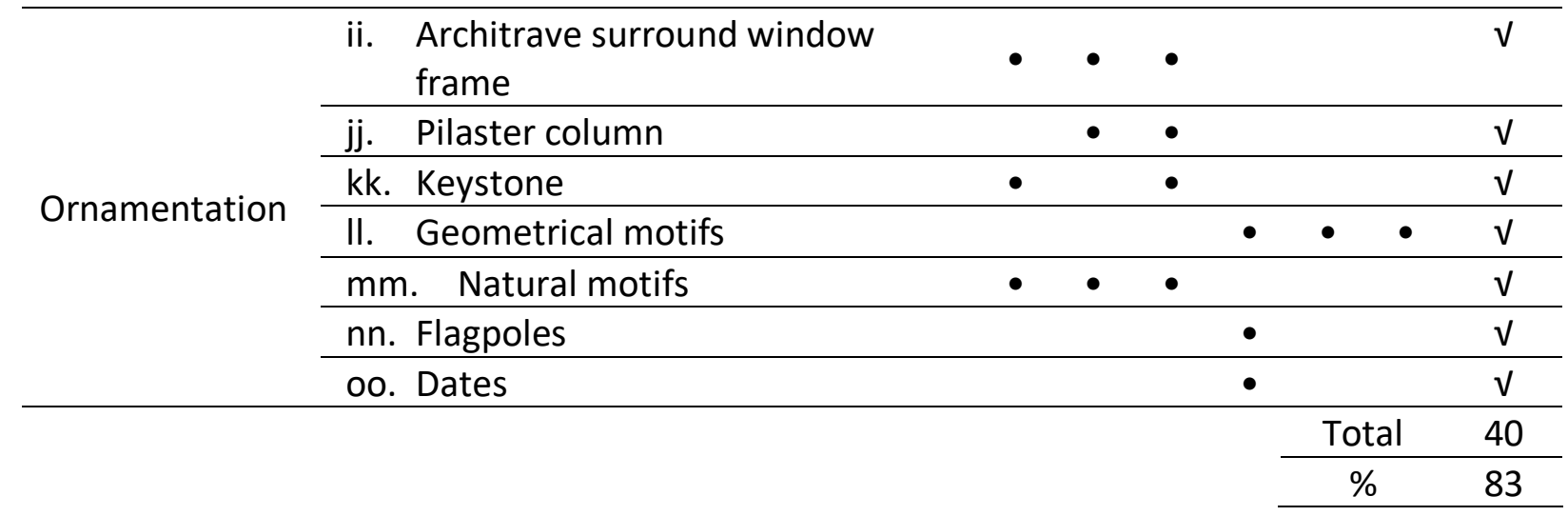

Table 5 shows that 40 characters differ among traditional and modern façade. This is one of the methods to classify the architectural styles by categorised it into major group, either traditional or modern. Table 6 summarising the characters of each category.

Table 6. Taxonomy of traditional and modern heritage shophouse façades.

\begin{tabular}{|c|c|c|}
\hline Main Features & Traditional & Modern \\
\hline \multirow{2}{*}{ 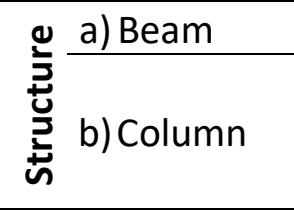 } & Load-bearing clay brick. & Reinforced concrete. \\
\hline & $\begin{array}{l}\text { Engaged column at the upper façade } \\
\text { and free-standing column below. }\end{array}$ & $\begin{array}{l}\text { Some of the shophouses having } \\
\text { traditional way of columns. 1970s } \\
\text { shophouses built without columns. }\end{array}$ \\
\hline \multirow{2}{*}{ 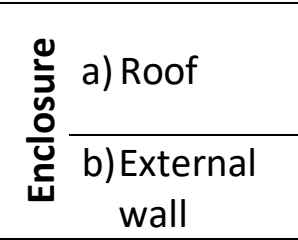 } & Pitch roof with terracotta roof tiles. & $\begin{array}{l}\text { Flat roof with membrane or pitch } \\
\text { roof hidden behind parapet wall. }\end{array}$ \\
\hline & Painted in pastel or white finishing. & Paint, Shanghai plaster or wall tiles. \\
\hline \multirow{3}{*}{ 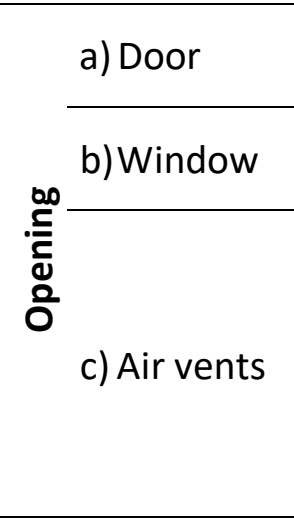 } & $\begin{array}{l}\text { Two timber shutter, removable } \\
\text { vertical timber or metal panelling. }\end{array}$ & $\begin{array}{l}\text { Two casement shutter, or timber or } \\
\text { metal folding paneling. }\end{array}$ \\
\hline & $\begin{array}{l}\text { Top part shutters has louvres, bottom } \\
\text { part is a flat panel. }\end{array}$ & $\begin{array}{l}\text { Casement shutters, glass louveres, } \\
\text { concrete shading fin. }\end{array}$ \\
\hline & $\begin{array}{l}\text { Simple carved timber air vent or slot } \\
\text { air vent either on the ground floor or } \\
\text { upper floor facade. Transoms light or } \\
\text { fanlight infilled with glass are often } \\
\text { combined timber carved or radiating } \\
\text { bars. }\end{array}$ & $\begin{array}{l}\text { Concrete slot, timber or metal } \\
\text { lattice at the ground level and } \\
\text { casement or louveres above } \\
\text { window. }\end{array}$ \\
\hline Fenestration & $\begin{array}{l}\text { Three bay windows full length } \\
\text { shutters. }\end{array}$ & $\begin{array}{l}\text { Windows size usually large and } \\
\text { arranged in group. }\end{array}$ \\
\hline Ornamentation & $\begin{array}{l}\text { Natural motifs, architrave and } \\
\text { classical features. Architrave framed } \\
\text { the window openings sometimes with } \\
\text { a keystone at the top. }\end{array}$ & Simple geometrical motifs. \\
\hline
\end{tabular}

\section{Conclusion}

Taxonomy of architectural style for heritage shophouses at Ipoh has contributed to the understanding on elements of heritage shophouse facades that can be used for documentation purposes, inventory, or re-inventory of heritage buildings, specifically 
shophouses. The main features of the facade is a set of criteria to identify the architectural style, whether traditional or modern. The research process acquired two-stages; literature search to get the code of the theme and then via a checklist. The information obtained from the field survey is processed by thematic coding. The overview of the study is show in Table 5. This taxonomy can also be expanded in more detail. It can be applied to any style of architectural facades found in the heritage area of Ipoh or in other areas that have a similar typology of heritage shophouse. In addition, it can be a reference for future research. It is recommended to study on evaluation tools for the physical condition of the facade from the architectural perspective.

\section{Acknowledgement}

The authors acknowledge with much appreciation for the financial support provided by the Ministry of Education (MOE) Malaysia, Universiti Sains Malaysia (USM) and Universiti Teknologi MARA (UiTM) Perak.

\section{Corresponding Author}

Wan Nordiana Wan Ali

School of Housing, Building and Planning, Universiti Sains Malaysia, Malaysia.

Email:wandiana2005@gmail.com

\section{References}

Ghafar, A. A. (2010). Pemuliharaan bangunan warisan di Malaysia; Pengalaman dan cabaran masa depan. Siri Syarahan Umum Pelantikan Profesor. Pulau Pinang: Penerbit Universiti Sains Malaysia.

Ahmad, S. H., \& Shaiful, R. C. Y. (2012). Architecture and heritage buildings in Georgetown Penang. Pulau Pinang: Penerbit Universiti Sains Malaysia.

Burden, E. (1996). Building facades: Faces, figures, and ornamental detail. London: McGrawHill.

Burden, E. (2003). Illustrated dictionary of architectural preservation. New York, United States: McGraw-Hill Companies.

Ching, D. K. (2012). A Visual dictionary of architecture (2 ${ }^{\text {nd }}$ ed.). New Jersey, United States: John Wiley \& Sons, Inc.

Comerma, B. I. (2008). Visual dictionary of architecture \& construction. Barcelona, Spain: Page One Publishing Pte Ltd.

Curl, J. S. (2006). A dictionary of architecture and landscape architecture ( $2^{\text {nd }}$ ed.). New York, United States: Oxford University Press.

Dogan, H. A. (2019). Assessment of the perception of cultural heritage as an adaptive re-use and sustainable development strategy case study of Kaunas, Lithuania. Journal of Cultural Heritage Management and Sustainable Development Vol. 9 No. 3, 2019 pp. 430-443. Emerald Publishing Limited. https://doi.org/ 10.1108/JCHMSD-09-2018-0066

Elnokaly, A., \& Wong, J. F. (2014). Demystifying vernacular shophouses and contemporary shophouses in Malaysia; A Green-Shop framework. In the 30th International PLEA Conference. Ahmedabad, India: CEPT University. Retrieved Aug 5, 2015 from http://www.plea2014.in/wp-content/ uploads/2014/12/Paper_3A_2601_PR.pdf

Fee, C. V. (2007). Architecture. The Encyclopedia of Malaysia, Vol 5. Kuala Lumpur, Malaysia: Archipelago Press.

Fielden, B. M. (2003). Conservation of historic buildings ( $3^{\text {rd }}$ ed.). Oxford: Architectural Press. 
Frontdesk. (n.d.). Peta Malaysia mungkin disemak semula. Retrieved February 20, 2020 from http://www.frontdesk.com.my /bm/index.php/ 2017/12/19/ peta-malaysia-mungkindisemak-semula/

Gurstein, P. (1990). Malaysian architectural heritage survey: A handbook. Kuala Lumpur, Malaysia: Badan Warisan Malaysia.

Harris, C. M. (1983). Illustrated dictionary of historic architecture. New York, United States: Dover Publications Inc.

Hopkins, O. (2013). Reading architecture: A visual lexicon. London: Laurence King Publishing Ltd.

Hornby, A. S. (2008). Oxford advanced learner's dictionary; International's student edition ( $7^{\text {th }}$ ed.). Oxford University Press.

Majlis Bandaraya Ipoh (MBI). (2012). Ipoh Local Plan 2020 (Rancangan Tempatan Ipoh 2020, Strategi dan Cadangan Pembangunan). Perak, Malaysia: Jabatan Perancangan Bandar dan Desa Perak Darul Ridzuan (JPBD Perak).

Majlis Bandaraya Ipoh (MBI). (2014). Special Area Plan of Ipoh City (Rancangan Kawasan Khas Pekan Ipoh; Bandar Warisan Bijih Timah 2020). Laporan Cadangan Pembangunan (Jilid I \& Jilid II). Perak, Malaysia: Jabatan Perancangan Bandar dan Desa Perak Darul Ridzuan (JPBD Perak).

Mughal, H. A. (2019). Support at Work and its Relationship with Employee Performance:

Critical Insights for Early Scholars. Annals of Contemporary Developments in

Management \& HR (ACDMHR), 1(3), 16-21.

Nik F. E. N. R. S., \& Mohd, T. M. R. (2017). Rumah teres dan keserasian budaya masyarakat Malaysia. Kuala Lumpur, Malaysia: Dewan Bahasa dan Pustaka.

Patwell, J. L., Craig, J. A., Cremans, D., Evenson, P. G., Innes, S. M., Katz, N. J., Marciano, J. P., Phelps, M. F., Previte, R. E., \& Schonthal, H. (2000). The American heritage dictionary of English Language ( $3^{\text {rd }}$ ed.). Houghton Mifflin Harcourt. Retrieved from https: //libgen.is/ book/ index. php? md5= 237044617ACB022597AF39BC542231B7

Shalunts G., Haxhimusa Y., \& Sablatnig R. (2011). Architectural style classification of building façade windows. In: Bebis G. et al. (eds) Advance in Visual Computing. ISVC 2011. Lecture Notes in Computer Science, vol 6939. Springer, Berlin, Heidelberg. https://doi.org/10.1007/978-3-642-24031-7_28

Tyler, N. (2000). Historic preservation; An introduction to its history, principles, and practice. New York, United States: W.W. Norton \& Company.

Vozniak. E., \& Butyrin, A. (2019). Classification of historical buildings façade's details on the basis of Order Theory. E3S Web of Conferences 91, 05016 (2019). TPACEE-2018. https://doi.org/10.1051/e3sconf /2019910 TPACEE-2018 5016

Wan, N. W. A., Noor, R. I., \& Azira, I. (2016). Heritage shophouses' building facade: The typology of architectural styles at Ipoh. Germany: Lambert Academic Publishing.

Wikimedia Commons. (n.d.). District in Perak. Retrieved February 20, 2020 from https:// commons.wikimedia.org/wiki/File: Districts_in_Perak.svg.

Wooi, T. Y. (2015). Penang shophouses; A Handbook of Features and Materials. Pulau Pinang, Malaysia: George Town World Heritage Incorporated. 